\title{
A study of store and retail attributes influencing the young Indian consumer buying decision
}

\author{
Shalini Yadav* and S.K. Garg \\ Delhi School of Management, \\ Delhi Technological University, \\ Shahbad Daulatpur, Main Bawana Road, \\ New Delhi, Delhi 110042, India \\ Email: shalini09.yadav@gmail.com \\ Email: skgarg63@yahoo.co.in \\ *Corresponding author
}

\begin{abstract}
Retail is passing through a critical phase in India and many alternative channels and store formats have evolved in the recent times. The young consumers' preferences have changed in the past decades due to improvement in purchasing power, increased options for shopping and globalisation. In this scenario, the manufacturers and the retailers are always in a dilemma regarding the retail and the store design to enhance the appeal of their products and services to the consumers'. The aim of this study is to identify the store and retail attributes which are most sought after by the young consumers' and to gauge the overall satisfaction with the Indian retail environment. The data obtained was analysed using descriptive statistics and exploratory factor analysis (EFA). The results reveal that the Indian youth is price and quality sensitive; attributes like easy accessibility and convenient location are identified to be crucial.
\end{abstract}

Keywords: consumer; retail attributes; store attributes; factor analysis; price; quality; easy accessibility and convenient location.

Reference to this paper should be made as follows: Yadav, S. and Garg, S.K. (2017) 'A study of store and retail attributes influencing the young Indian consumer buying decision', Int. J. Markets and Business Systems, Vol. 3, No. 1, pp.39-63.

Biographical notes: Shalini Yadav is currently pursuing her doctoral studies at Delhi School of Management, Delhi Technological University, Delhi, in the area of retail management. She earned her Bachelor of Arts from Delhi University and Masters in Business Administration from Lal Bahadur Shastri Institute of Management. Her area of interest includes retail and marketing.

S.K. Garg is a Professor of Delhi School of Management, Supply Chain Management and Quantitative Techniques. He is a Pro Vice Chancellor, Delhi Technological University, Delhi, India. His areas of interest include competitive strategies, JIT manufacturing systems, quality management, technology management and supply chain management. His publications have featured in journals such as International Journal of Manufacturing Technology and Management, International Journal of Productivity \& Quality Management and the International Journal of Services and Operations Management. 


\section{Introduction}

Organised retail is a recent phenomenon for the Indian consumer (Handa and Grover, 2012) and is growing at a very fast pace. According to a report titled 'Retail 2020: Retrospect, Reinvent, Rewrite', published by The Boston Consulting Group, the Indian retail sector is poised to grow up to 1 trillion USD by 2020 from 600 billion USD in 2015 (BCG, 2015). Attitudinal shift, an increase in income and urbanisation are fuelling this growth. The penetration level of modern retail (currently $5 \%$ ) is expected to increase six-fold from the current 27 billion USD to 220 billion USD in 2020. Largely, this growth will be driven by demographic changes. By 2020 , there will be a $70 \%$ upsurge in the income level and 100 million more youths will enter the workforce arena, says the study titled 'Retail Transformation: Changing Your Performance Trajectory' conducted by the Singhi et al. (2016).

Table 1 Age structure of India

\begin{tabular}{lc}
\hline Age & Percentage \\
\hline $0-14$ years & $27.71 \%$ \\
$15-24$ years & $17.99 \%$ \\
$25-54$ years & $40.91 \%$ \\
$55-64$ years & $7.3 \%$ \\
65 years and over & $6.09 \%$ \\
\hline
\end{tabular}

Source: CIA World Factbook (2016)

The key desirable element in the growth of India's population is evidently its young demographic. Currently, about $40.91 \%$ of the population is in the age bracket of 25-45 years and the median age is around 27.6 years (Table 1). This class signifies the most promising part of the population segment and is heavily contributing to India's consumption boom. Today, the young working population lives by the mantra - 'work hard and live well' and this has propelled the Indian retail market through the first decade of the millennium resulting in robust year-on-year growth and expansion over the last few years. This is indicative that the consumer demand should keep increasing for many years to come, boosting India's GDP. It also indicates that the products, services, skills and experiences available today will undergo a profound transformation to keep pace with the changing time. With the empowerment and influence of media, the spillover effect of urban consumer trends and styles has shown its sheen and influence on rural areas also. Increasing young population and the surge in workforce population has led to more disposable income which has resulted in new possibilities for retail growth even in the rural areas.

Consumer choice and preference play an important role in making marketing effort of any organisation meaningful or worthless. The changing consumption pattern trigger changes in shopping styles of consumers and hence acts as the factors that drive people into stores (Karim et al., 2013). The modern generation of consumers is entering a new age of consumption which is confusing and complex and at the same time - rich, intimate and extremely dynamic (Distefano et al., 2013). Therefore, to incorporate knowledge about consumer into every facet of a marketing plan is necessary. There are a number of 
variables which affect buying decision, namely: demographic, socio-environmental (such as the structure) and psychographic variables (Rindfleisch et al., 1997; Roberts, 1998, 2000).

Figure 1 Population pyramid of India (see online version for colours)

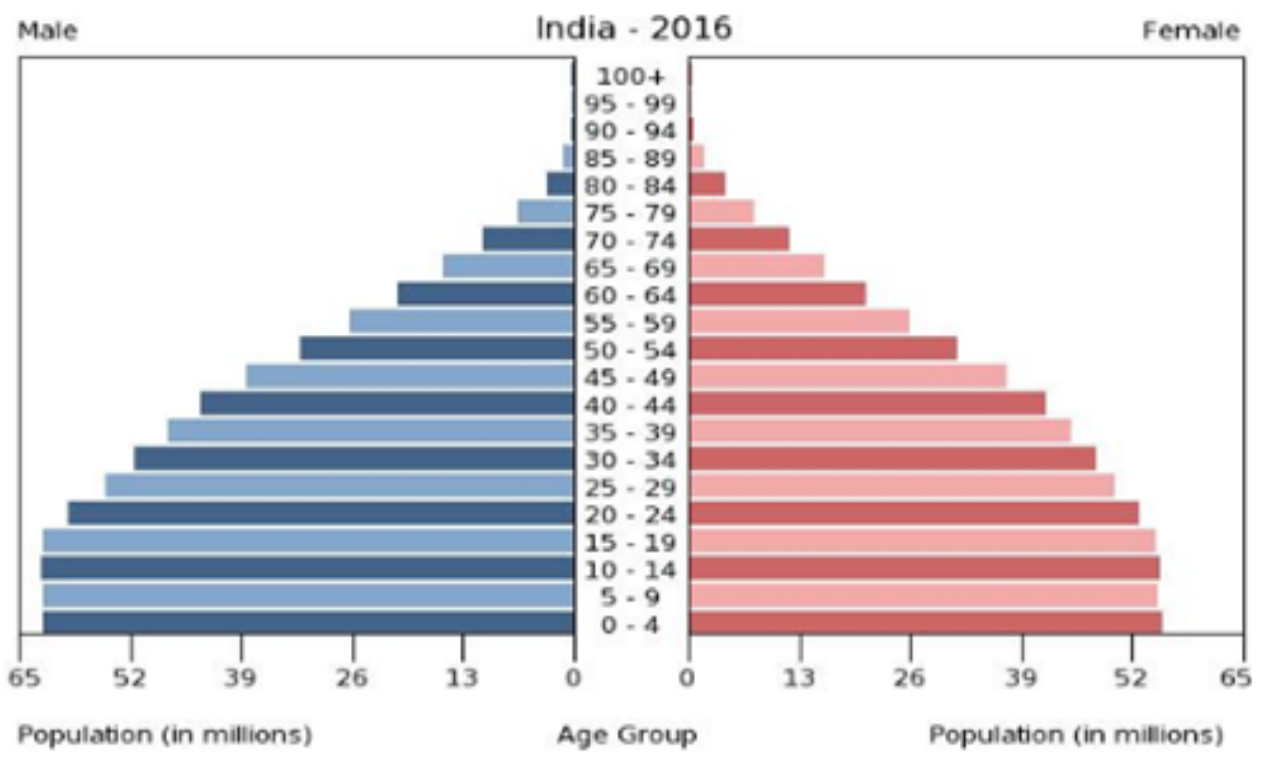

Source: CIA World Factbook (2016)

It is essential for store-based retailers to implement changes as per the consumers' requisite which would call for a clear understanding of which attributes affect consumers' preference (Paulins and Geistfeld, 2003). Along with the various characteristics of consumer perception and keeping various dimensions of consumer behaviour in mind, the organisations are also trying with different formats of retailing. The different retail formats that have evolved with time are - departmental stores, discount stores, warehouse stores, variety stores, mom-and-pop stores, specialty stores, general stores, convenience stores, hypermarket, supermarket, malls, category killer, e-tailer and vending machines. In any economy including India, no single format is universally acceptable for all products/societies. The same consumer may shop from a vendor, a mom-and-pop shop and also from a mall. Supercentres relish several strategic competitive advantages in comparison to traditional supermarkets, including the ability to sell items at lower prices and the proficiency to offer consumers the convenience of one-stop shopping. Likewise, some may use strategies such as product assortment differentiation and customer relationship management to create and serve niche markets (Hansen and Solgaard, 2004). Thus, a need was felt to understand the attributes most sought after by the consumer.

The rest of the paper is arranged as follows: Section 2 provides the literature review, Section 3 explains research methodology, Section 4 elaborates on results and discussions and finally Section 5 speaks of conclusion and limitations. 


\section{Literature review}

\subsection{Attributes influencing consumer preferences}

The literature is bursting with research which talks about numerous attributes that regulate the consumer preferences. They embrace attributes like behaviour of store personnel (O'Cass and Grace, 2008), store atmosphere, convenient location (Arnold and Tigert, 1982; Cravens, 2000; Sinha and Banerjee, 2004; González-Benito et al., 2007; Briesch et al., 2009), merchandise collection (Pan and Zinkhan, 2006), merchandise quality (Baltas and Papastathopoulou, 2003; Theodoridis and Priporas, 2009), price, services offered (Pan and Zinkhan, 2006), store character (Michman, 1991; Paulins and Geistfeld, 2003), fast checkout, suitable opening hours and apt parking services (Pan and Zinkhan, 2006). Service quality, customer perceived value, and satisfaction are greatly correlated and foretell the customer's repurchase behaviour (Rahman and Subramanian, 2012). In a significant work, Yavas (2003) assembled a set of attributes namely: price competitiveness, store variety, cleanliness, atmosphere, variety, quality, merchandise selection and courtesy of employee. Carpenter (2008) found that convenience, value and quality brands to be important attributes. Eroglu (2013) revealed the products' quality to be the most important attribute; on the contrary the store personnel criterion was insignificant for consumers. Zulqarnain et al. (2015) underlined the significance of factors such as price, variety, quality and location of stores as influencing people choices when they select a store for shopping. Further, Kiran and Jhamb (2016) emphasised the importance of quality, pleasant shopping environment, financing option, trial rooms for clothing products, return and exchange policies and competitive prices for the modern Indian consumer.

Many studies have further emphasised on the link between the retail attribute and the mall attractiveness (El-Adly, 2007; Wong et al., 2001). Sufficient parking, luxurious landscape, numerous shops, along with access to entertainment, and restaurants further enhances the lifestyle centre concept (Nooney, 2003). Yavas (2003) produced a related list of key attributes including quality, price, cleanliness, courtesy, assortment, security, store hours, accessibility, and atmosphere. The four key influencers which are imperative in making convenience store sites viable are footfall, the degree of available car parking, store visibility, and its design (Wood and Browne, 2007). As per Carpenter and Moore (2006), cleanliness, price competitiveness, product assortment and courtesy of personnel are the most important attributes considered while making a format choice. A similar list of attributes was given by Venkateshwarulu and Uniyal (2007). They recognised factors namely: appeal and convenience, amenities and atmospherics, ambience, personnel and parking and seating. This study incorporated new attributes like smell (odour), security, restroom (utilities), size of store. In a study of retail store selection in Malaysia, Wel et al. (2012) categorised the important determinants as: store personnel and physical characteristics of the store, peer influence, store convenience and merchandise selection, advertising, location, product quality and variety and services offered by store.

Store layout and display of products in store is another major influencer in moulding consumers' perception. Former research has specified few attributes, which contribute towards the store image namely - atmosphere, location, variety of merchandise, quality of merchandise, price, crowd, cleanliness and customer service (Baker et al., 1994; Bell, 1999; Bellizzi et al., 1983; Chebat et al., 1995; Dubé et al., 1995; Ibrahim and Chua, 2010; Ibrahim and McGoldrick, 2006; Milliman, 1982; Nevin and Huston, 1980; Sirgy 
et al., 2000). The store ambience relates to colour, furniture, décor, layout and design and its impact on the overall store environment. The positive prompts in the store environment encourage consumer patronage (Mehrabian and Russell, 1974; Baker et al., 1992, 1994; Donovan and Rossiter, 1982, 1994; Turley and Milliman, 2000). Hosseini et al. (2014) investigated the significant effects of store image attributes namely; store atmosphere, music, merchandise quality, service, price and convenience on customer perceptions. These factors improve consumer retailer affiliation and interaction.

\subsection{Service}

With more and more informative and demanding consumer; quality of the services offered by the stores has an important role to play (Lewis and Spyrakopoulos, 2001; Thang and Tan, 2003). In order to have a competitive edge, it is important to build and maintain high standard of services so as to gain and retain customer loyalty (Kandampully, 1998). As the consumer retention increases, cost decreases and leads to rising profits (Rust and Zahorik, 1993). Helpful attitude and personalised attention of the staff are significant in building long-term relationship with consumers and these services are hard to copy and replicate. Services include efficient handling of consumer complaints, guarantee concerning product returns and promotions (Lee et al., 2008). Social interaction and personalised attention by service personnel are two important considerations in services as identified by Beatty et al. (1996) and Mittal and Lassar (1996). Home (2002) advocates that consumers gave importance to location convenience, friendly service personnel, reliability, quick easy purchase and possibility of meeting acquaintances at the store while choosing a store. Sinha and Banerjee (2004) shared a similar view suggesting that for the Indian consumers location convenience and personal relationship with the shopkeeper were important attributes.

\subsection{Effect of age on retail choice}

Research advocates that age plays an important role in consumers' selection of store format (Burt and Gabbott, 1995; Wright, 1996; Kang and Ridgway, 1996; Lee et al., 2006; Joung and Miller, 2007; Carpenter, 2008; Carpenter and Balija, 2010). The younger consumers prefer more of trendy store formats and shows preference for branded stores (Lee et al., 2006). In an interesting study by Kaur and Singh (2007) revealed that young female consumers wanted enjoyable experiences in their shopping trips particularly when it came to shopping's hedonic and relaxing components. Young consumers desire for exciting shopping experiences, which are a combination of emotional and social needs and wants. This age group particularly relates with interaction and communication with other people. The attractiveness of these stores was mainly based on product or service quality and price but location and the behaviour of the shop assistants were also cited as influential (Yip et al., 2012).

\subsection{Retailer's perspective}

The studies by Lather and Kaur (2006) uncovered six main indicators of retail format: viz., price, sales personnel, quality of merchandise, assortment of merchandise, advertising services and convenience services that play key role for retailers in choosing 
the type of retail formats that may help them to cope up with the changing preferences of consumers. Mittal and Mittal (2008) suggest that the retailers marketing strategy will have to take into account two sets of attributes:

1 loyalty drivers

2 shopping experience enhancers.

Enjoyable pleasant and attractive, in-store shopping environment increases the chances of impulsive buying among consumers, says Tendai and Crispen (2009). According to Jain and Bagdare (2009) and Jacobs et al. (2010); layout, ambience, display, self-service, value added services, technology-based operations and many more dimensions with modern outlook and practices are the major determinants of modern retail formats. Robinson (1998) mentioned a need for consumer orientation rather than product orientation for future developments in retailing.

Review of literature presented a long list of important attributes that probably affect the consumer's buying intention. Authors felt the need to assimilate these diverse attributes and see their influence on buying decision. Present research was deliberated to carry out this integration and understand how these attributes relate with the young population.

\section{Objectives of the study}

The above discussions lead to the identification of the following scenario:

1 the retail sector is undergoing a change from unorganised to organised sector and from small shops to big stores and hypermarkets, hence, taking many forms and dimensions

2 the demographic profile of the society is changing with better purchasing capacity; focus on quality and convenience which has changed the consumer mindset and attitude

3 the opening of Indian retail sector to foreign players has heralded the consumer revolution.

For this scenario in India the following objectives are framed to study the consumer mindset and attitude to help the retailers in designing their formats:

a to identify the various stores and retail attributes which influence the young customers' buying behaviour

b to determine the relative importance of these attributes in Indian context through a questionnaire survey of young educated future consumers' who are going to influence and shape the future of retail markets

c to identify the major factors of retail attribute and store attribute using factor analysis to develop the strategic understanding of retail formats

d to know the overall satisfaction level of the consumers.

The scope of the study is limited to the Indian market. The respondents to the questionnaire are young educated males and females with international awareness. 


\section{Hypotheses of study}

The following hypotheses have been developed based on the objectives of the study.

H1 There is no significant relationship between store attributes and overall customer satisfaction with the Indian retail environment.

H2 There is significant relationship between retail attributes and overall customer satisfaction with the Indian retail environment.

\section{Research methodology}

To understand the attributes most sought after by the young population, a questionnaire-based study was carried out among the graduate and post-graduate students of University system in Delhi, India. Whiddon (1999) opined that college students are the probable earning group as they enter the workforce. They develop an inclination towards selected brands while in school and tend to remain loyal even during graduation. A total of 361 valid questionnaires were collected.

\subsection{Measurement}

The questionnaire was prepared after a detailed literature review on attributes sought after by the customer that induce them to buy a product or patronise a store. The questionnaire has mainly three parts. In part 1, the respondents were asked to rate the importance of different store attributes in influencing their buying decision; in part 2, their response were sought on the importance of retail attributes; and in part 3, the student's profile was captured. Review of literature resulted in a list of attributes affecting buying decision. Final instrument consisted of 37 attributes in all. Statements were organised to access respondents' level of agreement/disagreement to the statements signifying these attributes. Responses were documented on a five- point scale in which ' 1 ' represents very low and ' 5 ' represents very high. The questionnaire was tested for validity and reliability.

\subsection{Analysis}

A detailed literature review suggested that the customer perception variables as far as store attributes are concerned are: physical facilities at this store are visually appealing, free movement (aisle) space, easy accessibility, modern looking equipment and fixtures, general cleanliness and hygiene, convenient location, visual appeal of shopping bags, catalogues, convenient/long operational hours, this store accepts most major credit cards, good assortment of merchandise, parking convenience, well dressed and groomed staff, this store gives customer individual attention, courteous staff, high quality of product, the store perform the service right the first time and knowledgeable employees. The retail attributes includes: availability of foreign brands, after sales service, home delivery, better packaging, better customer service, better product quality, blend of shopping and entertainment, price, easy product exchange, fresh new stocks/exclusive, use of debit/credit card, customer loyalty card, quality assurance, better ambience, promotion offer, location/closeness to home, preferred brand/variety, brand image and goodwill, 
fixed price and convenient timing. Many statements were accepted from earlier studies of the aforesaid significant attributes. Of these, 37 attributes were shortlisted and carefully chosen by panel of experts to understand consumers' appreciation of attributes which were appropriately altered to suit the Indian context. The 37 attributes were segregated into store and retail attributes and factor analysed to reduce the data to meaningful factors. Exploratory factor analysis (EFA) was used with varimax rotation. The subsequent factors were identified using eigenvalues (greater than one criterion).

Reliability and validity of factor output was also checked using Cronbach's alpha value and average variance extracted. Simple percent and numbers were used on the demographic data collected with the help of a questionnaire. This data was used for profiling of young shoppers. EFA was done for the study using SPSS 21. Further KMO and Bartlett's test were used to measure sampling adequacy for this study. On the basis of EFA and percentages, inference was drawn about the research objectives. Regression analysis was done to find the significant association between the store and retail factors and the overall customer satisfaction with the Indian retail environment.

\section{Respondent's profile}

The sample taken for this research is young respondents in the age group of 20-26 yrs. A total of 361 valid questionnaires were collected, $46 \%$ from female and $54 \%$ from male (Table 2).

Table 2 Respondent's profile

\begin{tabular}{lccc}
\hline Demographic sets & Demographic subsets & Number & Percentage \\
\hline Gender & Male & $194(1.97)^{*}$ & 53.7 \\
& Female & $167(2.23)^{*}$ & 46.3 \\
\hline Last grade & Graduate & 357 & 98.9 \\
qualified & Post graduate & 4 & 1.1 \\
\hline Frequency of & Rarely & 54 & 15 \\
shopping & Frequently & 220 & 60.9 \\
& Very frequently & 87 & 24.1 \\
\hline
\end{tabular}

Note: *Mean value for shopping frequency.

\section{Data analysis and interpretation}

Cronbach's (alpha) is a coefficient of internal consistency (Cronbach, 1951). It is commonly used as an estimate of the reliability of a psychometric test for a sample of examinees. It is expressed as a number between 0 and 1 . Internal consistency describes the extent to which all the items in a test measure the same concept or construct and hence it is connected to the inter-relatedness of the items within the test. Higher values of are more desirable.

The internal consistency of items was assessed by computing the total reliability scale. The total reliability scale for the study is 0.731 for store variables and 0.797 for retail variables, indicating a good reliability (Table 3 ). 
Table 3 Reliability statistics

\begin{tabular}{lcc}
\hline & Store variables & Retail variables \\
\hline Cronbach's alpha & .731 & .797 \\
No. of items & 17 & 20 \\
\hline
\end{tabular}

\section{Exploratory factor analysis}

EFA is a statistical method used to unearth the primary structure of a comparatively large set of variables. EFA is a method within factor analysis which aims to categorise the underlying relationships between measured variables. Factor analysis helps in reducing the data and variable by combining two or more variables into groups of extremely correlated variables (Lee and Lee, 2011). Outsized variables can be reduced to a smaller number of variables, called factors, which capture considerable information from the original dataset (Parasuraman et al., 1994). Factor analysis is centred on three main assumptions (Jolliffe, 2002):

1 variables are linearly interrelated

2 data are interval scaled

3 the ranking given to any one variable (called factor loading) is partially the result of the impact of other variables.

One of the important techniques for factor analysis validity is Kaiser-Meyer-Olkin (KMO) measure of sampling adequacy. It compares the magnitudes of the observed correlation coefficients to the magnitude of the partial correlation coefficients. Kaiser (1974) and Kinnear and Gray (1994) recommended that a KMO value below 0.5 should be considered as unsatisfactory and therefore unacceptable. Bartlett's test of sphericity is used to test the significance level of the correlation coefficients between the variables. The test is significant if the p-value is smaller than 0.05 (Bartlett, 1951). Satisfying the above criterion, it is agreeable that all variables under these dimensions are suited for factor analysis (Table 4).

Table 4 KMO and Bartlett's test

\begin{tabular}{lcc}
\hline & Store variables & Retail variables \\
\hline Kaiser-Meyer-Olkin measure of sampling adequacy & 0.739 & 0.754 \\
Bartlett's test of sphericity & & \\
Approx. chi-square & $2,273.908$ & $2,808.994$ \\
Df & 136 & 190 \\
Sig. & 0.000 & 0.000 \\
\hline
\end{tabular}

While grouping the variables in factor the general rule postulates that only variables with factor loadings of 0.40 or higher on a factor should be considered (Ford et al., 1986). Varimax rotation was applied to provide a simple column structure for interpretation. After a series of deletions factor output was received in the form of five extracted factors for 17 store variable and six extracted factors for 20 retail variable problems. 
Table 5 Total variance explained for store variables

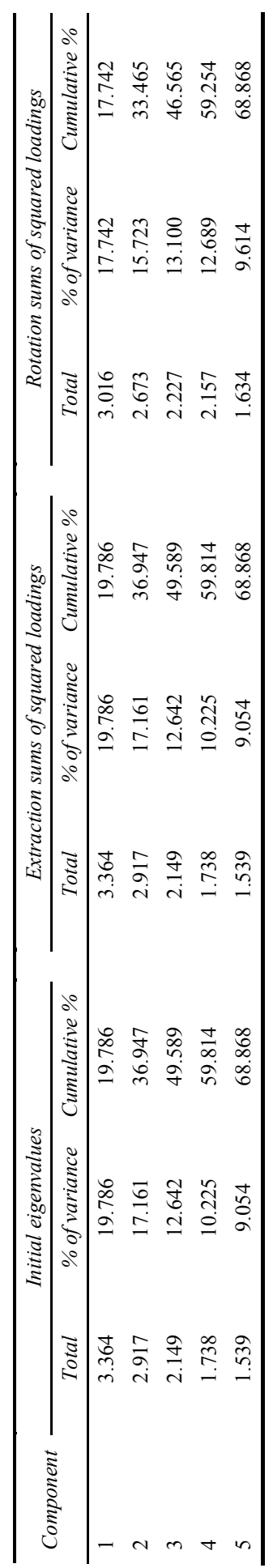


Table 6 Total variance explained for retail variables

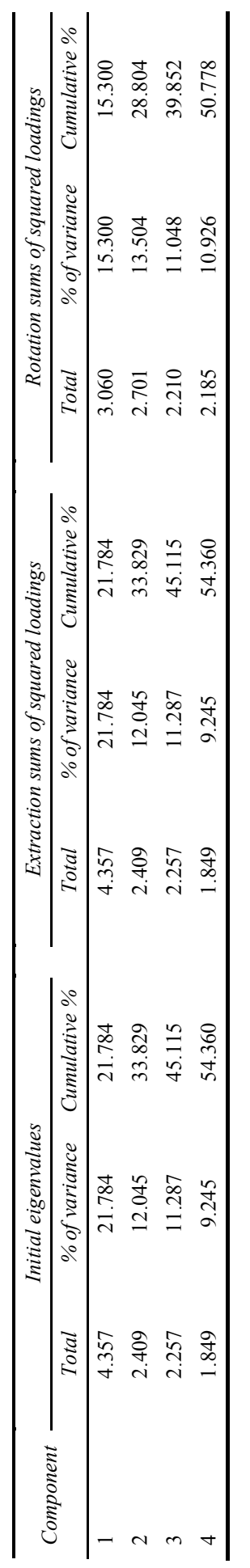


The factor analysis of these 37 statements resulted in five factors for store and six factors for retail with eigenvalue $>1$ (Table 5 and 6). Store factors accounted for $68.868 \%$ and retail factors account for $69.944 \%$ of the variance (which is satisfactory for social sciences) and had a KMO measure of sampling adequacy of 0.739 and 0.754 respectively, which is middling as per guidelines (Hair et al., 2003). Barlett's test of sphericity yielded a $\chi^{2}$ value of 2,273.908 at $136 \mathrm{df}$ for store variables and a $\chi^{2}$ value of $2,808.994$ at $190 \mathrm{df}$ for retail variables which is significant at 0.000 level, implying overall significance of the correlation matrix. Accordingly, the store factors were named: facilities at store, services provided at store, location of store, employee behaviour and product feature. The retail factors were named: service, product, suitability, price, brand and auxiliary.

Table 7 Consolidated store - factor output

\begin{tabular}{|c|c|c|c|c|c|c|c|}
\hline $\begin{array}{l}\text { Factor no. } \\
\text { (variance } \\
\text { explained) }\end{array}$ & $\begin{array}{c}\text { Factor } \\
\text { title }\end{array}$ & Variable included & $\begin{array}{l}\text { Avg. } \\
\text { score }\end{array}$ & $\begin{array}{l}\text { Factor } \\
\text { loading }\end{array}$ & $\begin{array}{l}\text { Cronbach } \\
\text { alpha }\end{array}$ & $\begin{array}{c}\text { Average } \\
\text { scorel } \\
\text { factor }\end{array}$ & $\begin{array}{l}\text { Factor } \\
\text { ranking }\end{array}$ \\
\hline \multirow[t]{5}{*}{$\begin{array}{l}\text { F1 } \\
17.74 \%\end{array}$} & \multirow[t]{5}{*}{$\begin{array}{l}\text { Facilities } \\
\text { at store }\end{array}$} & $\begin{array}{l}\text { Modern looking equipment } \\
\text { and fixtures }\end{array}$ & 3.83 & .853 & \multirow[t]{5}{*}{.831} & \multirow[t]{5}{*}{3.88} & \multirow[t]{5}{*}{$\mathrm{V}$} \\
\hline & & $\begin{array}{l}\text { Physical facilities at this } \\
\text { store are visually appealing }\end{array}$ & 3.84 & .776 & & & \\
\hline & & $\begin{array}{c}\text { General cleanliness and } \\
\text { hygiene }\end{array}$ & 4.21 & .715 & & & \\
\hline & & Free movement (aisle) space & 4.03 & .747 & & & \\
\hline & & $\begin{array}{l}\text { Visual appeal of shopping } \\
\text { bags, catalogues }\end{array}$ & 3.50 & .773 & & & \\
\hline \multirow[t]{4}{*}{$\begin{array}{l}\mathrm{F} 2 \\
15.72 \%\end{array}$} & \multirow{4}{*}{$\begin{array}{l}\text { Service } \\
\text { provided } \\
\text { at store }\end{array}$} & $\begin{array}{c}\text { Convenient/long operational } \\
\text { hours }\end{array}$ & 3.98 & .840 & \multirow[t]{4}{*}{.829} & \multirow[t]{4}{*}{3.98} & \multirow[t]{4}{*}{ III } \\
\hline & & $\begin{array}{l}\text { This store gives customer } \\
\text { individual attention }\end{array}$ & 3.97 & .782 & & & \\
\hline & & $\begin{array}{l}\text { The store perform the service } \\
\text { right the first time }\end{array}$ & 4.09 & .830 & & & \\
\hline & & $\begin{array}{l}\text { This store accepts most } \\
\text { major credit cards }\end{array}$ & 3.89 & .780 & & & \\
\hline \multirow{3}{*}{$\begin{array}{l}\mathrm{F} 3 \\
13.10 \%\end{array}$} & \multirow{3}{*}{$\begin{array}{l}\text { Location } \\
\text { of store }\end{array}$} & Easy accessibility & 4.41 & .872 & \multirow[t]{3}{*}{.811} & \multirow[t]{3}{*}{4.17} & \multirow[t]{3}{*}{ I } \\
\hline & & Convenient location & 4.16 & .878 & & & \\
\hline & & Parking convenience & 3.96 & .809 & & & \\
\hline \multirow{3}{*}{$\begin{array}{l}\text { F4 } \\
12.69 \%\end{array}$} & \multirow{3}{*}{$\begin{array}{l}\text { Employee } \\
\text { behaviour }\end{array}$} & Courteous staff & 3.96 & .889 & \multirow[t]{3}{*}{.800} & \multirow[t]{3}{*}{3.92} & \multirow[t]{3}{*}{ IV } \\
\hline & & $\begin{array}{l}\text { Well-dressed and groomed } \\
\text { staff }\end{array}$ & 3.80 & .848 & & & \\
\hline & & Knowledgeable employees & 4.00 & .766 & & & \\
\hline \multirow{2}{*}{$\begin{array}{l}\text { F5 } \\
9.61 \%\end{array}$} & \multirow{2}{*}{$\begin{array}{l}\text { Product } \\
\text { feature }\end{array}$} & High quality of product & 4.43 & .895 & \multirow[t]{2}{*}{.760} & \multirow[t]{2}{*}{4.08} & \multirow[t]{2}{*}{ II } \\
\hline & & $\begin{array}{l}\text { Good assortment of } \\
\text { merchandise }\end{array}$ & 3.73 & .898 & & & \\
\hline
\end{tabular}




\subsection{Factor analysis - store attributes}

Based on the factor loading in each pattern, the factor patterns were characterised as facilities at store, services provided at store, location of store, employee behaviour and product feature. The five factors explained $68.87 \%$ of total variance associated with the problem. Extracted factors are presented in Table 7.

\subsubsection{Factor 1 - facilities at store}

The first factor includes the physical oriented attributes of the store and explains $17.74 \%$ of variance. The presence of these attributes increases the benefits of shopping and acts as a facilitator in the decision making and buying process. Loadings for this factor range from 0.853 to 0.715 . This factor includes the following attributes: modern-looking equipment and fixture, physical facilities at the store are visually appealing, general cleanliness and hygiene of store, free movement space, and visual appeal of shopping bags/catalogue. Respondents have shown least agreement with this factor with the average factor score of (3.88). General cleanliness and hygiene and free movement (aisle) space have appeared as strongest attributes of this factor with an average score of 4.21 and 4.03 , respectively.

\subsubsection{Factor 2 - services provided at store}

The second factor includes service attributes of the store and explains $15.72 \%$ of variance. It comprises of four variables: convenient/long operational hours, the store gives customers individual attention, store performs the service right the first time, and the store accepts most credit cards. Loadings for this factor range from 0.840 to 0.780 . Average factor score of this factor is 3.98. The store provides the service right the first time with an average score of 4.09 has emerged as the most important variable for this factor.

\subsubsection{Factor 3 - location of store}

The third factor comprises of three variables (easy accessibility, convenient location and parking convenience) and explains $13.10 \%$ of variance. All these variables have considerably high factor loading (greater than 0.8 ) on this factor. Stores that are located near a bus interchange or mass rapid transit station are likely to enjoy additional exposure and pull greater traffic volume than stores that are not easily accessible. Average score of this factor is 4.17. The respondents have shown the highest support for this factor. Easy accessibility with an average score of 4.41 is the most important variable of this factor.

\subsubsection{Factor 4 - employee behaviour}

This store attribute includes the level to which the sales personnel gratifies the social desires of consumers and explains $12.69 \%$ of total variance. Knowledgeable and courteous staff will strengthen the store consumer relationship and boost repetitive visits 
and positive word-of-mouth spread by consumers to others. Knowledgeable employee with an average score of 4.00 is the most important variable of this factor. Loadings for this factor range from 0.889 to 0.766 . This factor includes the following allied variables: courteous employee, well-dressed and groomed staff and knowledgeable employees. Average score of this factor is 3.92 .

\subsubsection{Factor 5 - product feature}

The last factor comprises of two variables (high quality of product and good assortment of merchandise) and explains $9.61 \%$ of total variance. The variables in this factor have high factor loadings ranging from 0.898 to 0.895 . Average score of this factor is 4.08 . With an average score of 4.43 high quality of a product is declared as the most important variable for this factor.

Table 8 Consolidated retail - factor output

\begin{tabular}{|c|c|c|c|c|c|c|c|}
\hline $\begin{array}{l}\text { Factor no. } \\
\text { (variance } \\
\text { explained) }\end{array}$ & $\begin{array}{l}\text { Factor } \\
\text { title }\end{array}$ & Variable included & $\begin{array}{l}\text { Avg. } \\
\text { score }\end{array}$ & $\begin{array}{l}\text { Factor } \\
\text { loading }\end{array}$ & $\begin{array}{l}\text { Cronbach } \\
\text { alpha }\end{array}$ & $\begin{array}{c}\text { Average } \\
\text { scorel } \\
\text { factor }\end{array}$ & $\begin{array}{l}\text { Factor } \\
\text { ranking }\end{array}$ \\
\hline \multirow{5}{*}{$\begin{array}{l}\mathrm{F} 1 \\
15.30 \%\end{array}$} & \multirow[t]{5}{*}{ Service } & After sales service & 4.14 & .836 & \multirow[t]{5}{*}{.834} & \multirow[t]{5}{*}{4.01} & \multirow[t]{5}{*}{ IV } \\
\hline & & Better customer service & 4.18 & .803 & & & \\
\hline & & Easy product exchange & 3.93 & .730 & & & \\
\hline & & Home delivery & 3.88 & .698 & & & \\
\hline & & Use of debit/credit card & 3.94 & .733 & & & \\
\hline \multirow{4}{*}{$\begin{array}{l}\mathrm{F} 2 \\
13.50 \%\end{array}$} & \multirow[t]{4}{*}{ Product } & Better product quality & 4.38 & .843 & \multirow[t]{4}{*}{.832} & \multirow[t]{4}{*}{4.29} & \multirow[t]{4}{*}{ I } \\
\hline & & Quality assurance & 4.45 & .831 & & & \\
\hline & & Better packaging & 4.02 & .782 & & & \\
\hline & & $\begin{array}{c}\text { Fresh new } \\
\text { stocks/exclusive }\end{array}$ & 4.32 & .771 & & & \\
\hline \multirow[t]{3}{*}{$\begin{array}{l}\mathrm{F} 3 \\
11.04 \%\end{array}$} & \multirow[t]{3}{*}{ Suitability } & $\begin{array}{c}\text { Location/closeness to } \\
\text { home }\end{array}$ & 4.18 & .843 & \multirow[t]{3}{*}{.816} & \multirow[t]{3}{*}{4.14} & \multirow[t]{3}{*}{ II } \\
\hline & & Convenient timing & 4.13 & .874 & & & \\
\hline & & Better ambience & 4.12 & .797 & & & \\
\hline \multirow{3}{*}{$\begin{array}{l}\mathrm{F} 4 \\
10.92 \%\end{array}$} & \multirow[t]{3}{*}{ Price } & Fixed price & 3.90 & .893 & \multirow[t]{3}{*}{.804} & \multirow[t]{3}{*}{4.02} & \multirow[t]{3}{*}{ III } \\
\hline & & Price & 4.22 & .827 & & & \\
\hline & & Promotion offer & 3.93 & .784 & & & \\
\hline \multirow{3}{*}{$\begin{array}{l}\text { F5 } \\
10.85 \%\end{array}$} & \multirow[t]{3}{*}{ Brand } & Preferred brand/variety & 3.99 & .814 & \multirow[t]{3}{*}{.802} & \multirow[t]{3}{*}{3.92} & \multirow[t]{3}{*}{$\mathrm{V}$} \\
\hline & & $\begin{array}{l}\text { Brand image and } \\
\text { goodwill }\end{array}$ & 4.09 & .872 & & & \\
\hline & & $\begin{array}{l}\text { Availability of foreign } \\
\text { brands }\end{array}$ & 3.68 & .821 & & & \\
\hline \multirow{2}{*}{$\begin{array}{l}\mathrm{F} 6 \\
8.31 \%\end{array}$} & \multirow[t]{2}{*}{ Auxiliary } & Customer loyalty card & 3.63 & .877 & \multirow[t]{2}{*}{.744} & \multirow[t]{2}{*}{3.80} & \multirow[t]{2}{*}{ VI } \\
\hline & & $\begin{array}{c}\text { Blend of shopping and } \\
\text { entertainment }\end{array}$ & 3.98 & .869 & & & \\
\hline
\end{tabular}




\subsection{Factor analysis - retail attributes}

The six factors explain $69.94 \%$ of total variance associated with the problem. Extracted factors are presented in Table 6. Factors were labelled according to the dominant variables in the factor as follows: service, product, suitability, price, brand and auxiliary (Table 8).

\subsubsection{Factor 1 - service}

The first factor comprises of five retail attributes (aftersales service, better customer service, easy product exchange, home delivery, and use of debit card/ credit card) explains $15.30 \%$ of variance. Loadings for this factor ranges from 0.836 to 0.730 . Retailers attract customers not only with desirable products and affordable prices but also by offering services that enhance the purchase experience. In retail, it is an unexceptional and inseparable feature. A good service gives a competitive edge, which is important to have and to sustain, which help to gain and retain customer loyalty. Average score for this factor is 4.01. Emphasis is on better customer service in this factor with a high average score of 4.18 .

\subsubsection{Factor 2-product}

The second extracted factor explains $13.50 \%$ of total variance and comprises of four variables: better product quality, quality assurance, better product packaging and fresh new stock/exclusivity. Loadings for this factor vary from 0.843 to 0.771 . The most imperative challenge in retailing is the direct contact that a retailer establishes with the customer. The respondents have assigned highest importance to this factor with an average factor score of 4.29. The important variable for this factor is quality assurance with an average score of 4.45 .

\subsubsection{Factor 3 - suitability}

The third factor includes variables - location/closeness to home, convenient timing and better ambience. It explains $11.04 \%$ of variance. Factor loading for this case ranges from 0.874 to 0.797 . With long working hours and most family members working, store with closeness to home (average score of 4.15) and long operational hours (average score of 4.13) are becoming a necessity. The average score for this factor is 4.14 .

\subsubsection{Factor 4 -price}

The fourth factor comprises of three variables (fixed price, price, and promotion offer) and explains $10.92 \%$ of total variance. Factor loading ranges from 0.893 to 0.784 . Price act as a differentiator and helps in creates and establishing image of the brand in the eyes of the consumers. Average score for this factor is 4.02. Price (average score 4.22) has stood out as the most important variable for this factor. 


\subsubsection{Factor 5 - brand}

Brand helps to discriminate one's products from that of the competitor and also makes it easy for the customer to identify a product easily from the gamut available. This factor comprises of three variables: preferred brands/variety, brand image/goodwill, and availability of foreign brand, and explains $10.85 \%$ of variance. Factor loading is significantly high (greater than 0.8 ) for these variables. Average score for this factor is 3.92. Brand image/goodwill (average score 3.98) is the most important variable rated by young consumers.

\subsubsection{Factor 6-auxiliary}

The sixth extracted factor explains $8.31 \%$ of variance in total, comprising of two variables - customer loyalty card and blend of shopping and entertainment. These variables have significantly high factor loading (greater than 0.8) and an average factor score of 3.80. Blend of shopping and entertainment (average score 3.98) is rated high by the young generation for this factor.

\subsection{Factor ranking}

The value obtained by dividing the sum of average scores for all the variables constituting a particular factor by the number of variables creating that factor is used to determine the relevance of a factor. With an average factor score of 4.17 location of store is the most desired store factor and with an average score of 4.29 , product is the most desired retail factor. Facilities at store (3.88) and auxiliary (3.80) are the least significant store and retail factors respectively.

\section{Validity and reliability of factor output}

Validity and reliability for each factor for both store and retail attributes were tested statistically.

A Cronbach's alpha value of more than 0.7 was derived for all factors signifying reliability of output (Tables 7 and 8). Convergent validity was checked with the help of 'average variance extracted' (Tables 9 and 10). As a rule of thumb, the AVE of each construct should be at least 0.50 (Fornell and Larcker, 1981). Average variance extracted for store and retail factors is higher than 0.5 .

Table 9 Variance extracted by each store factor

\begin{tabular}{lllc}
\hline S. $n$ no. & & Factor number and title & Variance extracted \\
\hline 1 & F1 & Facilities at store & 0.507 \\
2 & F2 & Service provided at store & 0.554 \\
3 & F3 & Location of store & 0.613 \\
4 & F4 & Employee behaviour & 0.589 \\
5 & F5 & Product feature & 0.628 \\
\hline
\end{tabular}


Table 10 Variance extracted by each retail factor

\begin{tabular}{lllc}
\hline S. $n$ no. & & Factor number and title & Variance extracted \\
\hline 1 & F1 & Service factor & 0.509 \\
2 & F2 & Product factor & 0.562 \\
3 & F3 & Suitability factor & 0.605 \\
4 & F4 & Price factor & 0.593 \\
5 & F5 & Brand factor & 0.583 \\
6 & F6 & Auxiliary factor & 0.616 \\
\hline
\end{tabular}

\section{Hypothesis testing}

The hypothesis testing and regression analysis was done to fulfil the above said objectives of the study.

Table 11 Model summary ' 'store attributes'

\begin{tabular}{lccccc}
\hline Model & $R$ & $R$ square & Adjusted R square & Std. error of the estimate & Durbin-Watson \\
\hline 1 & $.700^{\mathrm{a}}$ & .490 & .483 & .703 & 1.697 \\
\hline
\end{tabular}

Notes: ${ }^{\text {P} P r e d i c t o r s: ~(c o n s t a n t), ~ e m p l o y e e ~ b e h a v i o u r, ~ f a c i l i t i e s ~ a t ~ s t o r e, ~ p r o d u c t ~ f e a t u r e, ~}$ location of store, service provided at store.

${ }^{b}$ Dependent variable: overall customer satisfaction with the Indian retail environment.

Table 12 Model summary 'retail attribute'

\begin{tabular}{lccccc}
\hline Model & $R$ & $R$ square & Adjusted $R$ square & Std. error of the estimate & Durbin-Watson \\
\hline 1 & $.622^{\mathrm{a}}$ & .387 & .377 & .772 & 1.611 \\
\hline Notes: & $\begin{array}{l}{ }^{2} \text { Predictors: (constant), product, auxiliary, price, brand, suitability, service. } \\
\text { bependent variable: overall customer satisfaction with the Indian retail } \\
\text { environment. }\end{array}$
\end{tabular}

Table 11 shows the association between store attributes and overall customer satisfaction with the Indian retail environment. The coefficient of correlation between different independent variables and the overall customer satisfaction with the Indian retail environment is 0.700 and the value of $\mathrm{R}^{2}$ is 0.490 . This implies that $49 \%$ of variation in dependent variable is described by various independent variables. Table 12 indicates the coefficient of correlation between different independent variables (retail attributes) and the overall customer satisfaction with the Indian retail environment is 0.622 and the value of $\mathrm{R}^{2}$ is 0.387 . This shows that $38 \%$ of variation in dependent variable is explained by various independent variables.

The results of hypothesis testing are reflected in Tables 13 and 14. Wherein, every beta coefficient describes the comparative significance of the affecting factor and customer satisfaction. All five factors of store and six factors of retail attributes are significant with a different value of beta coefficient, contributing different weights to the variance of overall customer satisfaction with the Indian retail environment. Therefore, both the null hypothesis is rejected and alternative hypothesis is accepted for store and retail attributes. Thus it can be concluded that: 
- there exists a significant impact of store attributes (facility at store, location of store, service provided at store, product features and employee behaviour) on overall customer satisfaction with the Indian retail environment

- there exists a significant impact of retail attributes (brand, auxiliary, service, suitability, price and product) on overall customer satisfaction with the Indian retail environment.

Table 13 Summary of testing hypothesis (store attributes)

\begin{tabular}{|c|c|c|c|c|c|c|}
\hline \multirow{2}{*}{\multicolumn{2}{|c|}{ Model }} & \multicolumn{2}{|c|}{$\begin{array}{c}\text { Unstandardised } \\
\text { coefficients }\end{array}$} & \multirow{3}{*}{$\begin{array}{c}\begin{array}{c}\text { Standardised } \\
\text { coefficients }\end{array} \\
\text { Beta }\end{array}$} & \multirow[t]{2}{*}{$t$} & \multirow[t]{2}{*}{ Sig. } \\
\hline & & $B$ & Std. error & & & \\
\hline \multirow[t]{6}{*}{1} & (Constant) & -3.309 & .397 & & -8.345 & .000 \\
\hline & Facilities at store & .376 & .054 & .265 & 6.932 & .000 \\
\hline & Location of store & .395 & .053 & .289 & 7.502 & .000 \\
\hline & Service provided at store & .318 & .051 & .242 & 6.191 & .000 \\
\hline & Product feature & .412 & .049 & .327 & 8.500 & .000 \\
\hline & Employee behaviour & .281 & .048 & .234 & 5.916 & .000 \\
\hline
\end{tabular}

Note: Dependent variable: overall customer satisfaction with the Indian retail environment.

Table 14 Summary of testing hypothesis (retail attributes)

\begin{tabular}{|c|c|c|c|c|c|c|}
\hline \multirow{2}{*}{\multicolumn{2}{|c|}{ Model }} & \multicolumn{2}{|c|}{$\begin{array}{c}\text { Unstandardised } \\
\text { coefficients }\end{array}$} & \multirow{3}{*}{$\begin{array}{c}\text { Standardised } \\
\text { coefficients }\end{array}$} & \multirow{3}{*}{$\begin{array}{c}t \\
-5.715\end{array}$} & \multirow{3}{*}{$\begin{array}{l}\text { Sig. } \\
.000\end{array}$} \\
\hline & & \multirow{2}{*}{$\frac{B}{-2.454}$} & \multirow{2}{*}{$\frac{\text { Std. error }}{.429}$} & & & \\
\hline 1 & (Constant) & & & & & \\
\hline & Brand & .232 & .057 & .178 & 4.093 & .000 \\
\hline & Auxilary & .189 & .049 & .166 & 3.860 & .000 \\
\hline & Service & .266 & .067 & .179 & 3.953 & .000 \\
\hline & Suitability & .344 & .059 & .260 & 5.877 & .000 \\
\hline & Price & .173 & .054 & .139 & 3.211 & .001 \\
\hline & Product & .347 & .067 & .225 & 5.206 & .000 \\
\hline
\end{tabular}

Note: Dependent variable: overall satisfaction with the Indian retail environment.

\section{Discussion}

For the young generation shopping experience has to be a gamut and composition of a number of nodes called the attributes. Marketers need to have a clear understanding of the drivers of enhancement of shopping experience. This can be done in accordance with the observations made in this research. 


\subsection{Configuration of factors}

For guaranteed survival in the face of intense competition, there is a crucial need for retailers and developers to distinguish themselves from the mass by offering innovative retailing concepts. In this research, the young consumers have given a direct verdict that shopping is a blend of factors. The young consumers have identified five factors for store attributes (facilities at store, employee behaviour, location of store, services provided at store and product feature) and six factors for retail attributes (service, product, suitability, price, brand, and auxiliary). The retailer provides a platform for interaction where the consumer gets to experience and get involved with the product directly. The result clearly indicates that clear planning and designing has to be integrated since the conceptualisation stage.

\subsection{Factors impact and significance}

Though the respondents have identified five store factors and six retail factors, it is clearly seen that all factors contribute differently towards the young generation's requirements. In the case of store attributes two factors (location of store and product feature) have an average score of more than four. Whereas, in the case of retail attributes, three factors (product, suitability, and price) have an average score of more than four. Both the result gives a clear indication that location and product are very significant for the young generation. 'Location of the store' is the leading factor defining store attributes which is apparent from the percent of variance explained by the factor and the high average factor score. 'Facilities at store' is least significant with an average factor score of 3.88, divulges the fact that too much of investment in accessorising the store may be a waste of money. Likewise, 'product' is the foremost factor outlining retail attributes with highest average score and percent of variance explained. The result of the research indicates that 'auxiliary' is least significant with an average factor score of (3.80). It is a clear signal that the consumer wants value for what they are paying. It cannot be compromised with frills and fancies provided by the retailers.

\subsection{Factor structure}

The research gives a fascinating understanding as to what institutes an individual factor. There is a clear indication that there is a distinction between managerial perception and shopper's description of attributes. Table 5 shows that easy accessibility (average score 4.41 ) is the largest contributor to the factor, 'location of store'. A look at factor, 'facility at store' reveals that general cleanliness and hygiene is considered as the greatest contributor and expected norm (average score 4.21). The result, further highlights that, the essence of success is in providing high-quality products (average score 4.43) to the consumer. Table 6 shows that quality assurance is the biggest contributor to the factor 'product' with average score of 4.45. The average score of all the variables of factor 'suitability' are high and resonate with each other very strongly indicating the importance 
the young generation places on ease of shopping. It is indicative of the fact that they want convenience while shopping in terms of location and operational hours. Low average value of factors - 'brand' (3.92) and 'auxiliary' (3.00), is a clear indication that the young consumers want value for money in terms of superior products and does not care much about the brand behind the products and embellishments. Foreign brands are no more guarantee for high-quality assurance and standards. Quality has the utmost significant role to play in building a store image (Baltas and Argouslidis, 2007; Baltas and Papastathopoulou, 2003).

\section{Conclusions}

A sudden proliferation in retail has led to a change in purchase and consumption behaviour and pattern. There are enormous possibilities, adding a new paradigm to the manufacturer-retailer-customer relationship, which has altered the shopper's expectations, needs, and perception which has called for the realignment of the choice-set of attributes offered by stores. It is essential for the retailers to make available those store attributes which are most desired by the target consumer. Sustaining the quality of these attributes is the toughest task and critical to survival in the competitive world (Ko and Kincade, 1997).

With respect to Indian retail market, the retailer and the consumer together are currently in an evolving stage. There is no clear pronouncement as to what would drive the young customer's choice in the long run. There has to be a judicious use of frills and fancies used to lure and attract the consumer. Today's young consumer is more aware and knowledgeable and is swamped with choices. Youth are the key consuming class because of time constraints in dual career families with high disposable incomes. With the retailers eyeing their presence in the market, it is pertinent for them to identify the target shoppers as well as to identify the prime reasons as to why they shop. Therefore, this paper brings forth the important dimensions of motivators for the youth when they shop. The results reveal that young consumers, interestingly, tend to shop not from a utilitarian perspective, but from a hedonic perspective.

Even with the growth of various at-home shopping services, time-starved consumers and consumers with internet affinity, shopping still calls for physical visits to a shopping location for most purposes. Rather, going shopping is a focal household chore, seen as a major source of relaxation and entertainment. It is evident from the research that the young generation only appreciates intervention and advice from the retail staff only when sought for. He is more quality conscious and willing to shell out extra money for the same. Furthermore, the inclination of men assuming a more egalitarian role due to gender role transcendence, along with growing pressure to share the shopping duties in today's time-crunched world, has added a new paradigm. Therefore, it can be concluded that success in the business hinges on identifying a good location, zeroing on a large enough audience and building the store around them, as per their requirements. It calls for seeing retailing with a different perspective and outlook. One has to be swayed by every opportunity to expand and build customer loyalty. It has to be understood that in the retail ecosystem all components work together in harmony, hand in hand, ignoring one would destroy the balance. To some extent, it calls for redefining the marketing mix according to current needs (Constantinides, 2006). 


\section{Limitations}

This research paper also has some limitations. The most important is the fact that this data replicate the behaviour of consumers only in Delhi and not in NCR or provincial towns, which may vary significantly. Another key limitation is that the sample in this study did not perfectly match the Indian young population. Studies with emulated samples to the young population are required. While we do provide valuable insight into the desired attributes of the young Indian population, we did not examine interaction effects between gender and other demographic characteristics such as income, education, occupation and household size, and so on. Future studies should consider such interaction. These demographic factors can present a different insight into consumers' expectations.

\section{References}

Arnold, S.J. and Tigert, D.J. (1982) 'Comparative analysis of determinants of patronage', in Lusch, R.F. and Darden, W.R. (Eds.): Retail Patronage Theory: 1981 Workshop Proceedings, Centre for Management and Economic Research, University of Oklahoma, Norman, OK.

Baker, J., Grewal, D. and Parasuraman, A. (1994) 'The influence of store environment on quality inferences and store image', Journal of the Academy of Marketing Science, Vol. 22, No. 4, pp.328-39.

Baker, J., Levy, M. and Grewal, D. (1992) 'An experimental approach to making retail store environmental decisions', Journal of Retailing, Vol. 68, No. 4, p. 445.

Baltas, G. and Argouslidis, P.C. (2007) 'Consumer characteristics and demand for store brands', International Journal of Retail \& Distribution Management, Vol. 35, No. 5, pp.328-341.

Baltas, G. and Papastathopoulou, P. (2003) 'Shopper characteristics, product and store choice criteria: a survey in the Greek grocery sector', International Journal of Retail \& Distribution Management, Vol. 31, No. 10, pp.498-507.

Bartlett, M.S. (1951) 'A further note on tests of significance in factor analysis', British Journal of Statistical Psychology, Vol. 4, No. 1, pp.1-2.

Beatty, S.E., Mayer, M., Coleman, J.E., Reynolds, K.E. and Lee, J. (1996) 'Customer-sales associate retail relationship', Journal of Retailing, Vol. 72, No. 3, pp.223-247.

Bell, S.J. (1999) 'Image and consumer attraction to intra-urban retail areas: an environmental psychology approach', Journal of Retailing and Consumer Services, Vol. 6, No. 2, pp.67-78.

Bellizzi, J.A., Crowley, A.E. and Hasty, R.W. (1983) 'The effects of colour in store design', Journal of Retailing, Vol. 59, No. 1, pp.21-45.

Boston Consulting Group (2015) Retail 2020: Retrospect, Reinvent, Rewrite [online] http://www.flandersinvestmentandtrade.com/export/sites/trade/files/news/724150312073614/ 724150312073614_1.pdf (accessed March 2016).

Briesch, R.A., Chintagunta, P.K. and Fox, E.J. (2009) 'How does assortment affect grocery store choice?', Journal of Marketing Research, Vol. 176, No. 47, pp.176-89.

Burt, S. and Gabbott, M. (1995) 'The elderly consumer and non-food purchase behaviour', European Journal of Marketing, Vol. 29, No. 2, pp.25-60.

Carpenter, J.M. (2008) 'Demographics and patronage motives of supercenter shoppers in the United States', International Journal of Retail \& Distribution Management, Vol. 36, No. 1, pp.5-16.

Carpenter, J.M. and Balija, V. (2010) 'Retail format choice in the US consumer electronics market', International Journal of Retail \& Distribution Management, Vol. 38, No. 4, pp. $258-274$. 
Carpenter, J.M. and Moore, M. (2006) 'Consumer demographics, store attributes, and retail format choice in the US grocery market', International Journal of Retail \& Distribution Management, Vol. 34, No. 6, pp.434-452.

Central Intelligence Agency (2016) World Factbook [online] https://www.cia.gov/library/ publications/the-world-factbook/geos/in.html (accessed 25 January 2107).

Chebat, J.C., Filiatrault, P., Gelinas-Chebat, C. and Vanisky, A. (1995) 'Impact of waiting attributions and consumers mood on perceived quality', Journal of Business Research, Vol. 34, No. 3, pp.191-196.

Constantinides, E. (2006) 'The marketing mix revisited: towards the 21 st century marketing', Journal of Marketing Management, Vol. 22, Nos. 3-4, pp.407-428.

Cravens, D.W. (2000) Strategic Marketing, 6th ed., McGraw-Hill, New York, NY.

Cronbach, L.J. (1951) 'Coefficient alpha and the internal structure of tests', Psychometrika, Vol. 16, No. 3, pp.297-334.

Distefano, A., Galvagno, M., Garraffo, F. and de Joannon, A. (2013) 'The role of brand quality in the elicitation of emotional aspects in young consumer-global brand relationships', Italian Marketing Society (SIM) - Annual Conference Proceedings.

Donovan, R.J. and Rossiter, J.R. (1982) 'Store atmosphere: an environmental psychology approach', Journal of Retailing, Vol. 58, No. 1, pp.34-57.

Donovan, R.J., Rossiter, J.R., Marcoolyn, G. and Nesdale, A. (1994) 'Store atmosphere and purchasing behaviour', Journal of Retailing, Vol. 70, No. 3, pp. 283-294.

Dubé, L., Chebat, J.C. and Morin, S. (1995) 'The effects of background music on consumers desire to affiliate in buyer-seller interactions', Psychology \& Marketing, Vol. 12, No. 4, pp.305-319.

El-Adly, M.I. (2007) 'Shopping malls attractiveness: a segmentation approach', International Journal of Retail \& Distribution Management, Vol. 35, No. 11, pp.936-950.

Eroglu, E. (2013) 'Factor affecting consumer preferences for retail industry and retailer selection using analytical hierarchy process', Kau iibf dergisi, Vol. 4, No. 6, pp.43-57.

Ford, J.K., MacCallum, R.C. and Tait, M. (1986) 'The application of exploratory factor analysis in applied psychology: a critical review and analysis', Personnel Psychology, Vol. 39, No. 2 , pp.291-314.

Fornell, C. and Larcker, D.F. (1981) 'Evaluating structural equation models with unobservable variables and measurement error', Journal of Marketing Research, Vol. 18, No. 3, pp.39-50.

González-Benito, O., Bustos-Reyes, C.A. and Munoz-Gallego, P.A. (2007) 'Isolating the geodemographic characterization of retail format choice from the effects of spatial convenience', Marketing Letters, Vol. 18, Nos. 1-2, pp.45-59.

Hair, J.F., Anderson, R.E., Tatham, R.L. and Black, W.C. (2003) Multivariate Data Analysis, pp.119-120, Pearson Education, Delhi.

Handa, V. and Grover, N. (2012) 'Retail sector in India: issues \& challenges', International Journal of Multidisciplinary Research, Vol. 2, No. 5, pp.244-264.

Hansen, T. and Solgaard, H.S. (2004) 'Measuring the effect of distance on consumer patronage behavior: a structural equation model and empirical results', New Perspectives on Retailing and Store Patronage Behavior: A Study of the Interface between Retailers and Consumers, pp.67-82, Kluwer Academic Publishers, Boston, MA.

Home, N. (2002) 'Rural consumers' patronage behaviour in Finland', The International Review of Retail, Distribution \& Consumer Research, Vol. 12, No. 2, pp.149-164.

Hosseini, Z., Jayashree, S. and Malarvizhi, C. (2014) 'Store image and its effect on customer perception of retail stores', Asian Social Science, Vol. 10, No. 21, p.223.

Ibrahim, M.F. and Chua, C.P. (2010) 'Permanent and temporary retail space: shoppers' perceptions of in-line stores and retail carts in Singapore', Journal of Property Investment \& Finance, Vol. 28, No. 2, pp.123-139. 
Ibrahim, M.F. and McGoldrick, P.J. (2006) 'Modelling shopping centre choices: effects of car ownership on clothing shopping in Singapore', Journal of Property Research, Vol. 23, No. 3, pp.189-214.

Jacobs, S., Merwe, D.V., Lomard, E. and Kruger, N. (2010) 'Exploring consumers' preferences with regard to department and specialist food stores', International Journal of Consumer Studies, Vol. 34, No. 2, pp.169-178.

Jain, R. and Bagdare, S. (2009) 'Determinants of customer experience in new format retail stores', Journal of Marketing \& Communication, Vol. 5, No. 2, pp.34-44.

Jolliffe, I.T. (2002) Principal Component Analysis, 2nd ed., Springer-Verlag, New York, New York.

Joung, H. and Miller, N.J. (2007) 'Examining the effects of fashion activities on life satisfaction of older females: activity theory revisited', Family and Consumer Sciences Research Journal, Vol. 35, No. 4, pp.338-356.

Kaiser, H. F. (1974) 'An index of factorial simplicity', Psychometrika, Vol. 39, No. 1, pp.31-36.

Kandampully, J. (1998) 'Service quality to service loyalty: a relationship which goes beyond customer services', Total Quality Management, Vol. 9, No. 6, pp.431-443.

Kang, Y. and Ridgway, N.M. (1996) 'The importance of market interactions as a form of social support for grey consumers', Journal of Public Policy and Marketing, Vol. 15, No. 1, pp.108-117.

Karim, J.A., Kumar, M. and Rahman, S.A. (2013) 'Measuring shopping values of Malaysian retail consumers', Asia Pacific Journal of Marketing and Logistics, Vol. 25, No. 2, pp.200-224.

Kaur, P. and Singh, S (2007) 'Uncovering retail shopping motives of Indian youth', Young Consumers, Vol. 8, No. 2, pp.128-138.

Kinnear, P.R. and Gray, C.D. (1994) SPSS for Windows Made Simple, Lawrence Erlbaum Associates Ltd, Hove.

Kiran, R. and Jhamb, D. (2016) 'An insight into product attributes and store attributes for consumer purchasing from emerging retail formats', Global Journal of Management and Business Research, Vol. 16, No. 1 [online] https://journalofbusiness.org/index.php/GJMBR/article/ view/1962 (accessed on 27 July 2017).

Ko, E. and Kincade, D.H. (1997) 'The impact of quick response technologies on retail store attributes', International Journal of Retail \& Distribution Management, Vol. 25, No 2 , pp.90-98.

Lather, A.S. and Kaur, T. (2006) 'Shopping malls: new retail formats keeping pace with the shoppers mood', The Journal of Indian Management and Strategy, Vol. 11, No. 4, pp.22-29.

Lee, M., Atkins, K., Kim, Y.K. and Park, S.H. (2006) 'Competitive analyses between regional malls and big-box retailers: a correspondence analysis for segmentation and positioning', Journal of Shopping Center Research, Vol. 13, No. 1, pp.81-98.

Lee, S-E., Johnson, K.K.P. and Gahring, S.A. (2008) 'Small-town consumers' disconfirmation of expectations and satisfaction with local independent retailers', International Journal of Retail and Distribution Management, Vol. 36, No. 2, pp.143-157.

Lee, Y. and Lee, H. (2011) 'Application of factor analysis for service R\&D classification: a case study on the Korean ICT industry', Expert Systems with Applications, Vol. 38, No. 3, pp.2119-2124.

Lewis, B.R. and Spyrakopoulos, S. (2001) 'Service failures and recovery in retail banking: the customers' perspective', International Journal of Bank Marketing, Vol. 19, No 1, pp.37-48.

Mehrabian, A. and Russell, J.A. (1974) An Approach to Environmental Psychology, MIT Press, Cambridge, MA.

Michman, R.D. (1991) Lifestyle Market Segmentation, Praeger, New York, NY.

Milliman, R.E. (1982) 'Using background music to affect the behavior of supermarket shoppers', Journal of Marketing, Vol. 46, No. 3, pp.86-91. 
Mittal, A. and Mittal, R. (2008) 'Store choice in the emerging Indian apparel retail market: an empirical analysis', IBSU Scientific Journal, Vol. 2, No. 2, pp.21-46.

Mittal, B. and Lassar, W.M. (1996) 'The role of personalization in service encounters', Journal of Retailing, Vol. 72, No. 1, pp.95-109.

Nevin, J.R. and Huston, M.J. (1980) 'Image as a component of attraction to intraurban shopping areas', Journal of Retailing, Vol. 56, No. 1, pp.77-93.

Nooney, P.A. (2003) 'Retail prevails: lifestyle centres put retail out in the open', The Journal of Property Management, Vol. 68, No. 5, pp.1-2.

O'Cass, A. and Grace, D. (2008) 'Understanding the role of retail store service in light of self-image-store image congruence', Psychology and Marketing, Vol. 25, No. 6, pp.521-537.

Pan, Y. and Zinkhan, G. (2006) 'Determinants of retail patronage: a meta-analytical perspective', Journal of Retailing, Vol. 82, No. 3, pp.229-243.

Parasuraman, A., Zeithaml, V.A. and Berry, L.L. (1994) 'Reassessment of expectations as a comparison standard in measuring service quality: implications for further research', Journal of Marketing, Vol. 58, No. 1, pp.111-124.

Paulins, V.A. and Geistfeld, L.V. (2003) 'The effect of consumer perceptions of store attributes on apparel store preference', Journal of Fashion Marketing and Management, Vol. 7, No. 4, pp.371-385.

Rahman, S. and Subramanian, N. (2012) 'Factors for implementing end-of-life computer recycling operations in reverse supply chains', International Journal of Production Economics, Vol. 140, No. 1, pp.239-248.

Rindfleisch, A., Burroughs, J.E. and Denton, F. (1997) 'Family structure, materialism, and compulsive consumption', Journal of Consumer Research, Vol. 23, No. 4, pp.312-325.

Roberts, J. (2000) 'Consuming in a consumer culture: college student, materialism, status consumption, and compulsive buying', Marketing Management Journal, Vol. 10, No. 2, pp.76-91.

Roberts, J.A. (1998) 'Compulsive buying among college students: an investigation of its antecedents, consequences, and implications for public policy', Journal of Consumer Affairs, Vol. 32, No. 2, pp.295-319.

Robinson, T. (1998) 'The role of retailing in a Russian consumer society', European Business Review, Vol. 98, No. 5, pp.276-281.

Rust, R.T. and Zahorik, A.J. (1993) 'Customer satisfaction, customer retention, and market share', Journal of Retailing, Vol. 69, No. 2, pp.193-215.

Singhi, A., Mall, A. and Puri, N. (2016) 'Retail transformation: changing your performance trajectory', CII National Retail Summit: 2016, The Boston Counsulting Group and Confedaration of Indian Industry [online] https://media-publications.bcg.com/india/RetailTransformation.pdf (accessed 27 July 2017).

Sinha, P.K. and Banerjee, A. (2004) 'Store choice behavior in an evolving market', International Journal of Retail \& Distribution Management, Vol. 32, No. 10, pp.482-494.

Sirgy, M.J., Grewal, D. and Mangleburg, T. (2000) 'Retail environment, self-congruity, and retail patronage: an integrative model and a research agenda', Journal of Business Research, Vol. 49, No. 2, pp.127-138.

Tendai, M. and Crispen, C. (2009) 'In-store shopping environment and impulsive buying', African Journal of Marketing Management, Vol. 1, No. 4, pp.102-108.

Thang, D.C.L. and Tan, B.L.B. (2003) 'Linking consumer perception to preference of retail stores: an empirical assessment of the multi-attributes of store image', Journal of Retailing and Consumer Services, Vol. 10, No. 4, pp.193-200.

Theodoridis, C.D. and Priporas, C-V. (2009) 'Store choice in computer retailing: the case of home users in Greece', EuroMed Journal of Business, Vol. 4, No. 1, pp.58-68.

Turley, L. and Milliman, R. (2000) 'Atmospheric effects on shopping behaviour: a review of the experimental evidence', Journal of Business Research, Vol. 49, No. 2, pp.193-211. 
Venkateshwarulu, A. and Uniyal, D.P. (2007) 'Concept of a mall: measuring attitude and perception of shoppers towards malls of Mumbai', Indian Retail Review, Vol. 2, No. 3, pp.215-235.

Wel, C.A.C., Hussin, S.R., Omar, N.A. and Nor, S.M. (2012) 'Important determinant of consumers' retail selection decision in Malaysia', World Review of Business Research, Vol. 2, No.2, pp.164-175.

Whiddon, R. (1999) 'Generation Y and college students embark on a lifelong shopping spree', IPO Repoeter, Vol. 23, No. 33, p.-3.

Wong, G.K.M., Lu, Y. and Yuan, L.L. (2001) 'SCATTR: an instrument for measuring shopping centre attractiveness', International Journal of Retail \& Distribution Management, Vol. 29, No. 2, pp.76-86.

Wood, S. and Browne, S. (2007) 'Convenience store location planning and forecasting - a practical research agenda', International Journal of Retailing \& Distribution Management, Vol. 35, No. 4, pp.233-255.

Wright, G. (1996) 'Aging boomers will revamp retail scene', Brandweek, Vol. 37, No. 39, p.18.

Yavas, U. (2003) 'A multi-attribute approach to understanding shopper segments', International Journal of Retail \& Distribution Management, Vol. 31, No. 11, pp.541-548.

Yip, T.C.Y., Chan, K. and Poon, E. (2012) 'Attributes of young consumers' favorite retail shops: a qualitative study', Journal of Consumer Marketing, Vol. 29, No. 7, pp.545-552.

Zulqarnain, H., Zafar, A.U. and Shahzad, M. (2015) 'Factors that affect the choice of consumers in selecting retail store, for grocery shopping', International Journal of Multidisciplinary and Current Research, Vol. 3. 